\title{
Website Interactivity and Promotional Framing on Consumer Attitudes Toward Online Advertising: Functional versus Symbolic Brands
}

\author{
Yu-Wen Li \\ National Sun Yat-sen University, Kaohsiung, Taiwan \\ d944020005@student.nsysu.edu.tw \\ Shu-Min Yang \\ Tax Collection Office, Kaohsiung \\ shumin11120@gmail.com \\ Ting-Peng Liang \\ National Chengchi University, Kaohsiung, Taiwan \\ tpliang@nccu.edu.tw
}

\begin{abstract}
In light of the rapid increase in the number of online consumers, advertising on websites is increasingly popular. However, previous research has indicated that consumers have negative attitude toward online advertisements. Hence, how to increase the effectiveness of online ads and understanding what factors affecting consumer attitudes toward website ads are important. This paper reports findings from an experiment that examined the effect of website interactivity, promotional framing (price discounts versus premiums), and different brand images (functional versus symbolic) on consumer attitudes toward the ads and toward the product in the advertisement. The results indicate that both website interactivity and promotional methods can enhance consumer attitudes, but price discount is effective only when the brand perception is functional but not effective when the brand image is symbolic.. The findings are valuable to advertisers and researchers in understanding factors that affect the effectiveness of website advertisements.
\end{abstract}

Keywords: Internet Advertising, Promotional Framing, Electronic Commerce, Brand Images, website interactivity 


\section{Introduction}

The rapid proliferation of the Internet and mobile technology has fundamentally changed the way people receive commercial information. Online advertising is almost inevitable for both sellers and consumers. A large body of research has been conducted on the design, appeal, and effects of online advertisements. Compared with traditional shopping channels (i.e. instore, mail-order, television, etc.), the Internet has become favorite for finding product information and purchasing products.

For companies that intend to take advantage of online advertising, it is important to know how to maximize the effect. They need to know what factors drive consumers' attitudes toward an advertisement and toward the advertised product. Three main directions have been investigated in previous literature. The first is the economic incentive provided in the advertisement is a sales promotion strategy, usually provided in two different ways: monetary (such as price discount) and nonmonetary premium (e.g., providing gifts). They are two different frames of economic incentives, and have different psychological effects on the consumer (e.g., Palazon and Delgado-Ballester, 2009). Most consumers would go with those they feel economically attractive.

The second factor is the design of advertisements (ads). Online ads are media for delivering information. Website functionality is known to have effects on the perception of the consumer (e.g., Liang and Lai, 2002; Teo, et al. 2003; Jiang et al. 2010). Prior research indicated that consumers have two major information needs when they surf the Internet: discount information and product information (Baye et al. 2003; Burke 2002; Kuruzovich et al. 2008; Viswanathan et al. 2007; Zettelmeyer 2000). Internet ads meeting such needs are more likely to be useful for online consumers, and to increase their attractiveness.
In addition to the ads itself, the third factor that may affect consumers' behavior is the value delivered by the advertised product. Most brands have their image positioning (e.g., Torelli et al. 2014). Luxury brands such as Chanel stresses its social value, while some other brands may focus on functional values. Most marketing literature indicates that consumers have very different expectations and behaviors when they purchase these two types of products. It's reasonable that consumers will react differently to messages in online ads for different types of products.

A large amount of research has investigated various aspects of these three factors separately, but not much has put them in a combined framework to study their respective effects. As most online ads are not relying on a single factor, its valuable to examine their combined effects. The objective of this research is to fill the gap by conducting an experiment to answer the following two questions:

(1) What are the respective effects of promotional framing strategy and design in online ads? and

(2) Whether different brand images play a role in online advertising?

The remainder of the paper is organized as follows. Section 2 reviews literature related to factors that affect the effect of online advertising. Section 3 describes the research model and hypothesis. Section 4 explains our research methodology. Section 5 discusses the findings and implications. Finally, we conclude the paper in Section 6.

\section{Literature Review}

Three factors are generally considered to affect consumer attitudes toward online ads: sales promotional strategy, advertisement design, and brand images. This section provides a review of relevant literature. 


\section{Sales Promotional Strategy}

Sales promotion is a common strategy in marketing. Economic incentives are a basic motivation for consumers and important for driving one's willingness to perform a behavior (Alba and Lynch 1997; Bénabou and Tirole 2003; Klein et al. 1997; Maclnnis et al. 1991). They also play a major role in influencing consumers' attitude toward an advertisement or intention to purchase (e.g., Chang 2004; Drossos et al. 2013; Maclnnis et al. 1991; Zhou and Bao 2002). Satisfying a consumers' economic needs can attract them to locate and recognize corresponding advertising content (Pieters and Wedel 2004; Zhou and Bao 2002). Consumer needs are generated from their expectations and experiences with online ads, such as their prior experiences, their online shopping experiences, and their general impressions of the Internet. Such needs would become motives for processing the received advertising messages, and further contribute to their evaluation of online ads.

Many studies have investigated the effect of incentives on one's attitude or behavior. For example, Maclnnis et al. (1991) argued that incentives can be viewed as consumers' readiness to process brand information in an advertisement. The higher level of incentives consumers have, the higher level of brand information processing from the advertisement may occur. In a recent paper, Drossos et al. (2013) contented that the attitude toward mobile ads was influenced by the incentive associated with the ad, and that the positive attitude may further affect the attitude toward brand and the intention to purchasing the advertised product. Once information on the Internet meets consumers' needs, it will influence consumers' attitude toward Internet messages. Consumers are inclined to pay attention to stimuli that make them feel well.

Sale promotion is a common method for providing incentives to consumers (Aydinli et al. 2014; Gong et al. 2015; Yi and Yoo 2011). There are many sale promotion tools such as price discounts, in-store demonstrations, coupons, sweepstakes and games, and premium (Shi et al. 2005). As a large amount of information exists on the Internet and the information search costs are quite low, consumers often focus more on product prices. As a result, consumers usually pay lower average prices on the Internet as compared with those who purchase offline (Baye et al. 2003; Viswanathan et al. 2007; Zettelmeyer 2000). This difference is not only because consumers can actively looking for lower prices but also because retailers offer lower prices online. Therefore, consumers tend to believe that online products are priced lower (Burke 2002; Chiang and Dholakia 2003; Kuruzovich et al. 2008). Such belief forms a reference point (i.e., expectation) for judging product messages on the Internet. As a result, economic incentives become essential for online sale promotion.

Economic incentives can be provided in two different forms: price discounts and premiums. They are two different frames of incentives: one is cost savings and another is benefit gaining. As it is well-known that different framing will generates different psychological effects stated in the prospect theory, different incentives frames have different effects. Most previous research reports a higher effect of price discounts (e.g., Campbell and Diamond, 1990; Palazon and Delgado-Ballester, 2009).

\section{Interactive Advertisement Design}

Design of ads is the second dimension that affects the effect of advertising. The Internet provides diversified, detailed, rich and useful shopping information. Its hierarchical structure of hyperlinks, multimedia interface design, and interactive characteristics helps consumers to navigate easily without losing interests over time (Gallagher et al. 2001; Tarafdar and Zhang 2005). Therefore, many previous studies have argued design criteria to be a key to website success. For example, Palmer (2002) addressed that website success is associated with several designs, such as interactivity, amount of product information, responsiveness, layout, 
display rate, and so on. Liang and Lai (2002) reported motivation and hygiene as two different roles of website functions. In marketing, Hoffman and Novak (1996) highlighted the importance of interactivity for communicating to online consumers. McMillan and Hwang (2002) further argued that interactivity could make the Internet advertisements more persuasive. They encouraged online advertisers to examining the interactivity of their Internet advertisements, and developed the measures for perceived interactivity.

The biggest advantage of the Internet is its interactivity and extensibility through hyperlinks, which enable consumers to obtain direct and immediate responses to their inquires about product information (Burke 2002; Viswanathan et al. 2007; Zettelmeyer 2000). In web advertising design, interactivity is considered a major factor. For instance, Zhou and Bao (2002) contended that an advertisement should provide utilitarian values and hedonic values to consumers. Consumers' utilitarian needs can be satisfied by providing well-organized and plentiful product information, while their hedonic needs can be satisfied by providing social pleasure. These two requirements can be achieved by interactive advertising.

More specifically, an advertisement could build a user-message interaction with consumers. This kind of interactivity may allow the consumers to control the messages they receive based on their own needs (Liu and Shrum 2002; Sundar and Kim 2005). It provides not only the useful product information to consumers but also the experience of an interaction that can bring social values to consumers. The wellorganized hyperlinks enable consumers to get detailed product information they need from Internet advertising. When clicking on a hypertext link, consumers may go to a webpage that presents the information they require. The clicking motion can be viewed as the motion of making request. The information displayed on a webpage is just the response to consumers' request. This is similar to an inter-personal interaction that can satisfy one's social needs (Nass and Moon 2000).

As a result, such interactions can affect consumers' attitude and behavior. Teo et al. (2003) reported that the level of interactivity positively influence consumers' perceived satisfaction, effectiveness, efficiency, value, and attitude towards a Web site. Liu and Shrum (2009) argued that interactivity has positive effect on persuasion, and its effect may vary depending on consumers' involvement and Internet usage experience. Jiang, et al. (2010) stated that websites with a high level of active control lead to cognitive involvement and, in some instances, affective involvement. Drossos et al. (2013) further demonstrated that interactivity has the significant effect on consumers' attitude toward advertising. As the consumers become relying on the Internet, the need for interactivity that enables them to obtain rich information has increased (Kuruzovich et al. 2008). Hence, online ads that offer organized product information through hyperlinks are likely to be more effective.

\section{Brand Image}

Brand image refers to consumers' total impression of a product category, which is formed by the attributes and the benefits of the product category (Dobni and Zinkhan 1990). There are many brand positioning strategies that involve communicating the brand image to consumers and differentiate the brand from other product categories in marketing (Park et al. 1986). In general, brand images convey not only abstract meanings but also values to consumers. Torelli et al. (2014) argued that brand image is just the representations of human values. It can elicit a consumer's sense that a brand could bring benefits to him/her. These expected benefits, then, translate into an abstract concept, and influence consumers' attitude and their purchasing intention (Aggarwal et al. 2011; Ailawadi et al. 2006; Berens et al. 2005; Pieters and Wedel 2004). Since brand image is important in marketing, the way to build or strengthen a 
brand image has received great attentions. For example, Delgado-Ballester and Hernández-Espallardo (2008) found that an unknown brand can increase its image by association with a well-known brand. Lam et al. (2013) contended that brand positioning could help the formation of consumer-brand identification. Bellezza and Keinan (2014) claimed that non-core consumers' brand image can be enhanced by eliciting their pride. Researchers have explored ways to develop powerful brand images for enhancing marketing effects.

Based on consumers needs, brand images can be divided into two common types - functional and symbolic (Bhat and Reddy 1998; Nan and Heo 2007; Park et al. 1986). Functional brand focuses on utilitarian values, while symbolic brand focuses on social and hedonic values. Functional-branded products are designed to fulfill consumers' immediate and practical needs. Consumers care about the performance of a functional product and product quality is usually important for a functional brand. As for symbolic brands, products are designed to fulfill consumers' needs of self-expression and prestige. The main reason for consumers to buy symbolic products is to express their desired identities (Bellezza and Keinan 2014). As different brand images may bring different benefits to consumers, it is reasonable to anticipate that brand images will interfere with the effect of advertising.

\section{Research Model and Hypothesis}

Based on our literature review, a research model, as shown in Figure 1, can be proposed. The model includes promotional framing and interactivity design as two independent variables, brand images as a moderator and advertising effectiveness as the dependent variable.

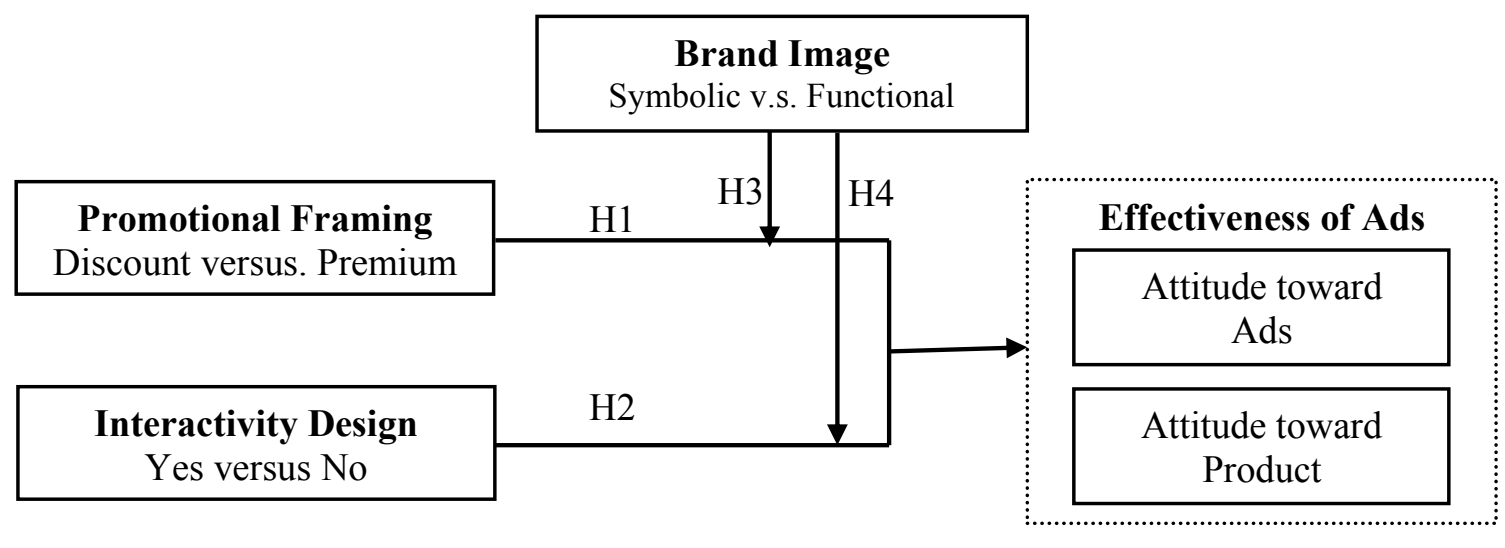

\section{Figure 1 - Research Model}

\section{Effect of Monetary Incentives}

Several previous studies have shown that sales promotion significant affects consumers' purchasing attitude and behavior (Compeau and Grewal 1998; Darke and Chung 2005; Naylor et al. 2006; Yi and Yoo 2011). As stated in the previous section, sales promotion can be divided into monetary (price discount) and nonmonetary (premium) (Chandon et al. 2000). Compared with non-monetary promotion, monetary promotion is more attractive on the Internet. Prior research has reported that consumers expect online prices to be lower than offline (Baye et al. 2003; 
Zettelmeyer 2000). Consumers usually navigate shopping websites with the expectation of finding a lower price (Chiang and Dholakia 2003; Viswanathan et al. 2007). Monetary incentives have become major appeals of Internet advertising (Cao et al. 2003; Jensen et al. 2003). Palazon and Delgado-Ballester (2009) also found that price discounts are more effective than premiums, although their effects differ in different promotional benefit levels.

Since consumers expect to get a price-off in the online context, online ads with price discounts may better meet their expectations and result in positive evaluation of the advertisement and the advertised product (McKinney et al. 2002; Raghunathan et al. 2006). Generally speaking, online consumers are impulsive and sensitive to price promotions (Donthu and Garcia 1999; Gong et al. 2015). The excitement of getting a low price bargain and the satisfaction with discounts would induce positive mood (Schindler 1989). This emotional effect would then transform into persuading power, and advertising effectiveness. That is, monetary promotion in an advertisement could lead to stronger positive attitude toward advertising messages than non-monetary promotion (Jensen et al. 2003). Therefore, the following hypotheses are prosited:

Hypothesis 1a: Discount-oriented advertisements have a stronger positive impact on consumers' attitude toward advertising than premium-oriented advertisements.

Hypothesis 1b: Discount-oriented advertisements have a stronger positive impact on consumers' attitude toward product than premium-oriented advertisements.

\section{Effect of Interactivity}

Interactive features of the Internet encourage consumers to obtain information actively instead of merely receiving it passively (Chiang and Dholakia 2003; Gallagher et al. 2001; Moe 2003).
Interactivity also enables consumers to control what messages they receive. It is particularly helpful for processing information, because consumers could selectively focus on the part they need and facilitate their systematic elaboration (Liu and Shrum, 2009). From the information processing perspective, better control and elaboration have a significant impact on persuasion (Petty and Cacioppo 1986). Interactivity can enhance advertising persuasion (Drossos et al. 2013; Liu and Shrum 2009; Liu and Shrum 2002; Sundar and Kim 2005).

Hence, an interactive advertisement designed with a hierarchical structure of hyperlinks can be assumed to have a better effect because this kind of well-organized advertising messages not only help consumers to easily find the information they need but also contribute to their elaboration on advertising messages. Based on this argument, the following two hypotheses are proposed:

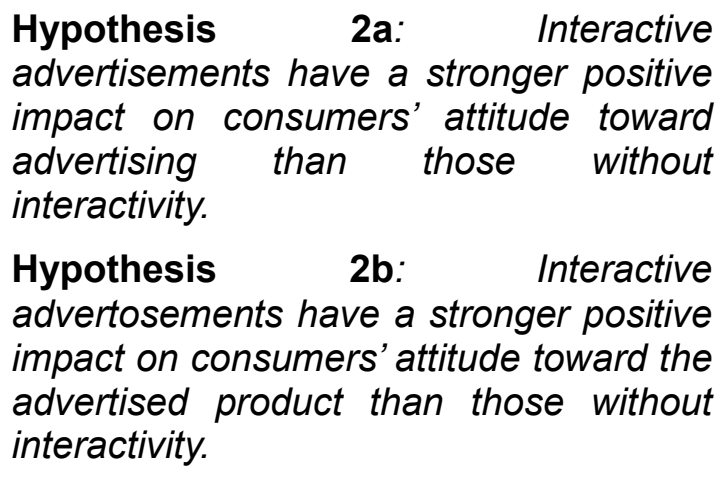

\section{The Moderating Role of Brand Image}

As different brand images tend to appeal different consumer values, they may play roles in influencing a consumers' attitude and purchasing intention. Prior research indicates that price promotion is more effective than premium but benefit levels vary for price and premium strategies (e.g., Palazon and Delgado-Ballester 2009). Some others report that price discount may signal low quality and have negative effect on consumers' attitude toward a brand (e.g., DelVecchio et al. 2006; Yi and Yoo 2011). This negative effect may be stronger when 
brand image is symbolic, which usually emphasizes social and hedonic value of a product. When consumers view ads for a symbolic product, they may focus on extrinsic benefits of the product and pay less attention to product price. Therefore, we posit the following hypotheses:

Hypothesis 3a: The impact of discountoriented advertisements on consumers' attitude toward advertising is moderated by brand image-the effect of price discount will reduce when the brand image is symbolic than when it is functional.

Hypothesis $\mathbf{3 b}$ : The impact of discountoriented advertisements on consumers' attitude toward the advertised product is moderated by brand image - the effect of price discount will reduce when the brand image is symbolic than when it is functional.

The moderating effect of brand images may also exist between interactivity and advertising effectiveness. For example, Liu and Shrum (2002) argued that interactivity is not always a good thing, and its effects on enhancing positive attitudes may vary when their motivation for browsing differs. Since symbolic brands stress social and hedonic benefits, additional product information included in an interactive advertisement may not be so interesting to the consumer. Therefore, we posit the following two hypotheses:

Hypothesis 4a: The impact of advertisements with interactivity on consumers' attitude toward advertising is moderated by brand images-the impact of interactivity will reduce when the brand image is symbolic than when it is functional.

Hypothesis 4b: The impact of advertisements with interactivity on consumers' attitude toward a product is moderated by brand images-the impact of interactivity will reduce when the brand image is symbolic than when it is functional.

\section{Research Methodology}

In order to test the hypotheses, we conducted a lab experiment in which each participant viewed an Internet advertisement on a website. A $2 \times 2 \times 2$ between-subjects factorial design was employed. The manipulated variables were promotional framing (price discount vs. premium), interactivity design (yes vs. no), and brand image (functional vs. symbolic).

\section{Advertisement Manipulation}

Promotion messages were framed into two different types - price discount and premium. A 40 percent discount was offered in priceoriented ads whereas gifts worth about 40 percent of the listed price were offered in premium-oriented ads. Ads with interactivity were designed to have additional product information such as product description, product ingredients, directions for use, and matters requiring attention by clicking hyperlinks. Figure 2 shows sample ads in different designs.

\section{Measurement Development}

Measurements of advertising effectiveness and brand image were developed according to available literature. Two dependent variables were used to represent the effectiveness of advertising: attitude toward the ads and attitude toward the advertised products. Attitude toward the advertisement refers to the general feeling about the advertisement and was measured by three attributes: informativeness, entertainment, and credibility (Brackett and Benjamin N. Carr 2001, Tsang, Ho and Liang 2004). Attitude toward the product refers to the general feeling about the advertised product, and it was measured by the perceived quality and value of the product (Berens et al. 2005; Dodds et al. 1991).

Brand images include symbolic and functional. The symbolic image of a brand was measured by five items for assessing consumers' perception of the degree to which the brand satisfies their symbolic needs. The functional image of a brand was 
measured by four items for assessing consumers' perception of the degree to which the brand satisfies their functional needs (Bhat and Reddy 1998). All items were measured on a seven-point Likert scale, with 1 indicating the least agreed and 5 indicating the most agreed. Questionnaire items are listed in Appendix 1.

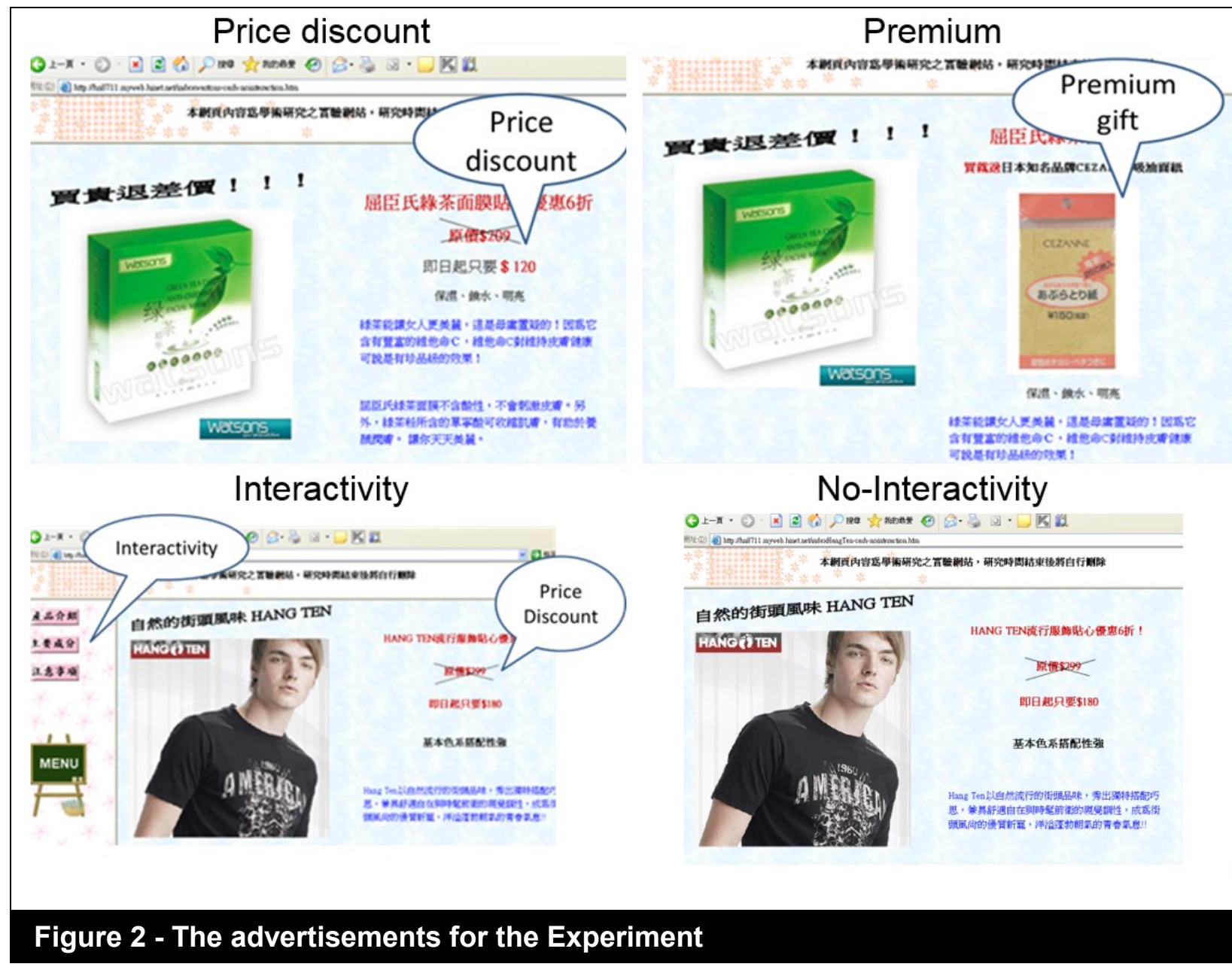

\section{Pretest of Instruments}

In order to manipulate different types of brand images, a pilot test was conducted to choose suitable brands in Taiwan. We selected four product categories for the pretest: clothing, electronics, cosmetics, and sport shoes. We then identified a symbolic brand and a functional brand for each product category. Two hundred students were randomly assigned into four groups. Each group was asked to evaluate whether a brand image was symbolic or functional for a product category. The collected data were then analyzed. We eliminated electronics and athletic shoes, because the discrepancy of image between symbolic and functional brands was not significant.

\section{Data Collection}

The participants of the formal study were 240 students from a national university in Southern Taiwan. They were randomly assigned to one of the eight experimental groups. An experimental website was built to display specifically designed advertisements. Each participant was asked to log into the experimental website and view the assigned advertisement. After viewing the experimental ads, the 
participants fill out a questionnaire to assess the effectiveness of advertising and the brand image of the product in the advertisements.

After removing incomplete responses, a total of 216 valid cases were available for further analysis. For functional products, the functional perceptions of the products were stronger than symbolic perceptions $(\mathrm{t}=$ $26.581, p=0.000)$. For symbolic products, the symbolic values were stronger than the functional ones ( $t=26.747, p=0.000)$. Therefore, the symbolic brand group has stronger symbolic brand images, whereas the functional brand group has stronger functional brand images. The brand image was manipulated successfully.

\section{Data Validity}

We used factor analysis to evaluate the reliability and validity of the questionnaire. A principal component analysis with the varimax rotation was applied to check the factor structure. All items converged into intended factors and did not load highly on other factors, supporting the discriminant validity and convergent validity (Hair et al. 2006). Moreover, Cronbach's alpha values ranged from 0.7 to 0.9 , indicating a high internal consistency considering a minimum threshold of 0.7 (Nunnally and Bernstein 1994). The results are shown in Appendix 2.

\section{Findings and Implications}

A MANOVA analysis was conducted on the collected data to examine the effects of promotional framing and advertisement interactivity, along with the moderating role of brand images. Descriptive data of advertising effects are shown in Table 1, and the MANOVA results are shown in Table 2.

\section{The Promotional Framing Effect}

As shown in Tables 1 and 2, price discount generates significantly higher attitude scores toward the advertisement than those of the premium strategy. Since most consumers expect lower prices from online offers, the results are not surprising and are consistent with previous literature, Hypothesis 1a is supported.

The results also show a significant main effect on the attitude toward the product. Consumers' attitude toward the product was more positive in the discount setting than that in the premium setting. Hence, hypothesis 1b was supported. This result indicates that lower price does not cause a suspicion about product quality. This is also consistent with marketing literature that argues no strong link between price and perceived quality in general (e.g., Zeithaml, 1988). However, as the interaction effect between promotion strategy and brand image is significant, we need also to look into their interaction before making any conclusion.

\section{Table 1 - Descriptive Statistics of Advertising Effects}

\begin{tabular}{|l|c|c|}
\hline & Attitude toward Ads M(SD) & Attitude toward Product M(SD) \\
\hline Promotional framing & $4.02(0.914)$ & $4.23(0.960)$ \\
$\quad$ Price discount & $3.78(0.884)$ & $3.99(1.300)$ \\
Premium & $4.48(0.661)$ & \\
Ad Interactivity & $3.33(0.735)$ & $4.13(1.102)$ \\
$\quad$ Interactivity & $4.09(1.199)$ \\
\hline No-interactivity &
\end{tabular}




\begin{tabular}{|c|c|c|c|}
\hline Source & Dependent Variable & $\mathrm{F}$ & Sig. \\
\hline \multirow[t]{2}{*}{ Promotional framing } & Attitude toward Ads & 4.979 & $0.027^{*}$ \\
\hline & Attitude toward Product & 10.217 & $0.002^{* \star}$ \\
\hline \multirow[t]{2}{*}{ Interactivity } & Attitude toward Ads & 147.643 & $0.000^{* \star \star}$ \\
\hline & Attitude toward Product & 0.213 & 0.645 \\
\hline \multirow[t]{2}{*}{ Brand Image } & Attitude toward Ads & 1.022 & 0.313 \\
\hline & Attitude toward Product & 550.299 & $0.000^{* * *}$ \\
\hline \multirow[t]{2}{*}{ Promotion $\times$ Interactivity } & Attitude toward Ads & 1.401 & 0.238 \\
\hline & Attitude toward Product & 0.153 & 0.696 \\
\hline \multirow[t]{2}{*}{ Promotion $\times$ Brand Image } & Attitude toward Ads & 5.568 & $0.019^{*}$ \\
\hline & Attitude toward Product & 21.335 & $0.000^{* * *}$ \\
\hline \multirow[t]{2}{*}{ Interactivity $\times$ Brand Image } & Attitude toward Ads & 0.677 & 0.411 \\
\hline & Attitude toward Product & 0.495 & 0.482 \\
\hline \multirow[t]{2}{*}{ Promotion $\times$ Interactivity $\times$ Brand Image } & Attitude toward Ads & 0.777 & 0.379 \\
\hline & Attitude toward Product & 3.866 & $0.051^{\#}$ \\
\hline
\end{tabular}

Note: \# p close to $0.05,{ }^{*} p<0.05,{ }^{* *} p<0.01,{ }^{* * *} p<0.001$

\section{Effects of Interactivity}

The main effect of interactivity on consumer attitude toward the advertisement was significant. Higher interactivity design through providing hyperlinks in online ads generated a more preferable attitude toward the ads. Hypothesis $2 a$ is supported. This may be because additional product information provided by hyperlinks in the advertisement not only makes it more informative but also makes online consumers to feel better controls of messages. This is consistent with previous literature. For example, Jiang, et al. (2010) reported that "website with a high level of active control lead to cognitive involvement and, in some instances, affective involvement." Palla et al. (2013) argued that "high interactivity leads consumers to generate positive thoughts regarding the website. High interactivity in a website leads to the peripheral process of the product related information."

With respect to product attitudes, interactivity does not lead to significantly preferred attitude toward the product. Hypothesis 2b was not supported. Since Interactivity design provides no additional value other than friendly access to product information, its contribution may not be strong enough to change consumers' evaluation of a product. There is no significant interaction effect between interactivity and brand image. Hence, the main effects are valid.

\section{The Moderating Role of Brand Images}

The moderating effect of brand images is observed from their interactions with promotional framing and interactivity. As we can see in Table 2, the interaction effect of promotion and brand images is statistically significant for both attitude toward the ads and attitude toward the product. Figure 3 illustrates the interaction effect, which shows that the effect of price discount was significantly higher for functional brands but was not statistically significant for symbolic brands. This supports Hypothesis 3a. Indeed, prices may not be a major concern when the brand image is symbolic. As shown in Figure 3(a), the attitude toward the advertisement is higher for symbolic products in the premium-oriented ads but is lower in the discount-oriented advertisement.

Figure 3(b) shows the product attitudes for functionally positioned brands. The average attitude score is higher for products in discount-oriented ads than that in premiumoriented ads. When the brand position is symbolic, however, the attitude toward the 
product becomes no difference in two promotional frames. This result also supports the moderating effect of brand image on the attitude toward the product. Therefore, hypothesis $3(\mathrm{~b})$ is supported.
The interaction effect between interactivity and brand image is not significant for both attitudes, as shown in Table 2. Thus, hypotheses 4(a) and 4(b) are not supported.

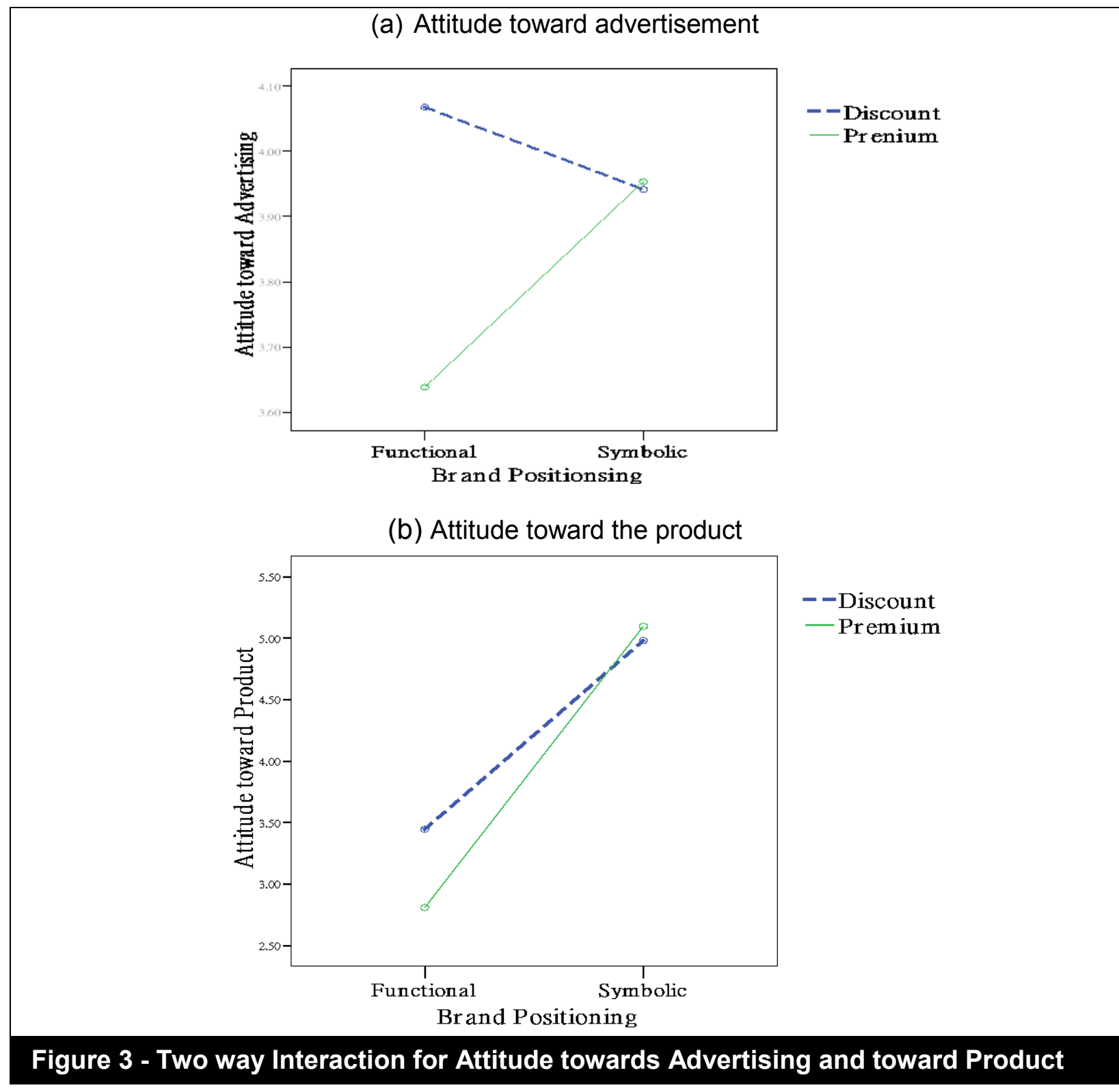

\section{Conclusion}

Online advertisement is a popular means for product promotion. In this research, we have conducted an experiment to investigate three main factors that may affect the effectiveness of online advertising: economic incentives in sales promotion (price discount vs. premium), interactivity of the ads, and brand image (symbolic vs. functional). These three factors represent three dimensions of consumer expectations: economic gain, friendly information access, and product value. 
The findings are as follows. First, price discount is more effective than premium in enhancing consumers' attitude toward the advertisement and attitude toward the advertised product. Second, Online ads with interactivity can enhance consumers' attitude toward the advertisement but has no significant effect on consumers' attitude toward the advertised product. Third, the above effects vary when brand images are positioned differently. The impacts of price discount are significant for functionally positioned brands but not for symbolically positioned ones. No significant difference is found for the premium strategy. Finally, brand image does not moderate the influence of interactivity on consumer attitudes.

The findings have theoretical and practical contributions. Theoretically, we have found different effects of economic incentives, ad interactivity, and brand images. This implies that different sales promotion strategies must be used in practice, when the brand image is positioned differently. Price discount are useful for functionally positioned products while the premium strategy may be considered for symbolically positioned products.

Since the conclusion is based on a single experiment, generalization of our findings to other contexts needs to be careful. The experimental study has inherent limitations in external validity, as the experimental setting may not fully reflect the real advertising situation. Nonetheless, our study is one of the first to investigate three factors together and report different effects of promotional framing and interactivity design when brands are positioned differently. The findings contribute to our understanding of the complex effects of promotional framing, online advertisement design, and brand images.

\section{Acknowledgements}

This research was partially supported by the Top University Project to National Sun YatSen University from the Ministry of Education.

\section{References}

Aggarwal, Preveen, Sung Youl Jun, and Jong Ho Huh (2011), "Scarcity Messages : A Consumer Competition Perspective," Journal of Advertising, 40 (3), 19-30.

Ailawadi, Kusum L., Bari A. Harlam, Jacques Cesar, and David Trounce (2006), "Promotion Profitability for a Retailer: The Role of Promotion, Brand, Category, and Store Characteristics," Journal of Marketing Research, XLIII, 518-35.

Alba, Joseph and John Lynch (1997), "Interactive Home Shopping: Consumer, Retailer, and Manufacturer Incentives to Participate in Electronic Marketplaces," Journal of Marketing, 61 (3), 38-53.

Aydinli, Aylin, Marco Bertini, and Anja Lambrecht (2014), "Price Promotion for Emotional Impact," Journal of Marketing, 78, 80-96.

Bénabou, Roland and Jean Tirole (2003), "Intrinsic and Extrinsic Motivation," Review of Economic Studies, 70 (3), 489-520.

Baye, Michael R., John Morgan, and Patrick Scholten (2003), "The Value of Information in an Online Consumer Electronics Market," Journal of Public Policy \& Marketing, 22 (1), 17-25.

Bellezza, Silvia and Anat Keinan (2014), "Brand Tourists: How Non-Core Users Enhance the Brand Image by Eliciting Pride," Journal Of Consumer Research, 41 (2), 397-417.

Berens, Guido, Cees B.M. van Riel, and Gerrit H. van Bruggen (2005), "Corporate Associations and Consumer Product Responses: The Moderating 
Role of Corporate Brand Dominance," Journal of Marketing, 69 (July), 35-48.

Bhat, Subodh and Srinivas K. Reddy (1998), "Symbolic and Functional Positioning of Brands," Journal of Consumer Marketing, 15 (1), 32-43.

Burke, Raymond R. (2002), "Technology and the Customer Interface: What Consumers Want in the Physical and Virtual Store," Journal of the Academy of Marketing Science, 30 (4), 411-32.

Campbell, Leland, William D. Diamond (1990) "Framing and Sales Promotions: The Characteristics of a 'Good Deal'", Journal of Consumer Marketing, 7(4), pp.25 - 31.

Cao, Yong, Thomas S. Gruca, and Bruce R. Klemz (2003), "Internet Pricing, Price Satisfaction, and Customer Satisfaction," International Journal of Electronic Commerce, 8 (2), 31-50.

Chandon, Pierre, Brian Wansink, and Gilles Laurent (2000), "A Benefit Congruency Framework of Sales Promotion Effectiveness," Joumal of Marketing, 64 (4), 65-81.

Chang, Chingching (2004), "The Interplay of Product Class Knowledge and Trial Experience in Attitude Formation," Journal of Advertising, 33 (1), 83-92.

Chiang, Kuan-Pin and Ruby Roy Dholakia (2003), "Factors Driving Consumer Intention to Shop Online: An Empirical Investigation," Journal of Consumer Psychology, 13 (1\&2), 177-83.

Compeau, Larry D. and Dhruv Grewal (1998), "Comparative Price Advertising: An Integrated Review," Journal of Public Policy and Marketing, 17, 257-13.

Darke, Peter R. and Cindy M.Y. Chung (2005), "Effects of Pricing and Promotion on Consumer Perceptions: It Depends on How you Frame It," Journal of Retailing, 8 (1), 35-47.

Delgado-Ballester, Elena and Miguel Hernández-Espallardo (2008), "Effect of Brand Associations on Consumer Reactions to Unknown On-Line Brands," International Journal of Electronic Commerce, 12 (3), 81-113.
DelVecchio, Devon, David H. Henard, and Traci H. Freling (2006), "The Effect of Sales Promotion on Post-Promotion Brand Preference: A Meta-Analysis," Journal of Retailing, 82 (3), 203-13.

Dobni, Dawn and George M. Zinkhan (1990), "In Search of Brand Image: A Foundation Analysis," Advances in Consumer Research, 17 (1), 110-19.

Dodds, William B., Kent B. Monroe and Dhruv Grewal (1991), "Effects of Price, Brand, and Store Information on Buyers' Product Evaluations," Journal of Marketing Research, 28(3), 307-319

Donthu, N. and A. Garcia (1999), "The Internet Shopper," Journal of Advertising Research, 39 (3), 52-58.

Drossos, Dimitris A., George M. Giaglis, Pavlos A. Vlachos, Efpraxia D. Zamani, and George Lekakos (2013), "Consumer Responses to SMS Advertising: Antecedents and Consequences," International Journal of Electronic Commerce, 18 (1), 105-36.

Gallagher, Katherine, K. Dale Foster, and Jefrey Parsons (2001), "The Medium Is Not the Message: Advertising Effectiveness and Content Evaluation in Print and on the Web," Journal of Advertising Research, 41 (4), 57-70.

Gong, Jing, Michael D. Smith, and Rahul Telang (2015), "Substitution or Promotion? The Impact of Price Discounts on Cross-Channel Sales of Digital Movies," Journal of Retailing, 91 (2), 343-57.

Hoffman, Donna L. and Thomas P. Novak (1996), "Marketing in Hypermedia Computer-Mediated Environments: Conceptual Foundations," Journal of Marketing, 60 (3), 50-68.

Jensen, Thomas, Jeremy Kees, Scot Burton, and Fernanda Lucarelli Turnipseed (2003), "Advertised Reference Prices in an Internet Environment: Effects on Consumer Price Perceptions and Channel Search Intentions," Journal of Interactive Marketing, 17 (2), 20-33.

Jiang, Z., J. Chan, B.C.Y. Tan, and W.S. Chua (2010), "Effects of Interactivity on Website Involvement and Purchase 
Intention," Journal of AIS, Volume 11, Issue 1, pp. 34-59.

Klein, Barbara D., Daie L. Goodhue, and Gordon B. Davis (1997), "Can Humans Detect Errors in Data? Impact of Base Rates, Incentives, and Goais," MIS Quarterly, 21 (2), 169-94.

Kuruzovich, Jason, Siva Viswanathan, Ritu Agarwal, Sanjay Gosain, and Scott Weitzman (2008), "Marketspace or Marketplace? Online Information Search and Channel Outcomes in Auto Retailing," Information Systems Research, 19 (2), 182-201.

Lam, Son K., Michael Ahearne, Ryan Mullins, Babak Hayati, and Niels Schillewaert (2013), "Exploring the Dynamics of Antecedents to Consumer-Brand Identification with a New Brand," Journal of the Academy of Marketing Science, 41 (234-252).

Liang, T.P. and H.J. Lai, (2002), "Effect of store design on consumer purchases: an empirical study of on-line bookstores," Information \& Management, Volume 39, Issue 6, pp. 431-444.

Liu, Y. and L.J. Shrum (2002), "What Is Interactivity and Is It Always Such a Good Thing? Implications of Definition, Person, and Situation for the Influence of Interactivity on Advertising Effectiveness," Journal of Advertising, XXXI (4), 53-64.

Liu, Y. and L. J. Shrum (2009), "A DualProcess Model of Interactivity Effects," Journal of Advertising, 38 (2), 53-68.

Maclnnis, Deborah J., Christine Moorman, and Bernard J. Jaworski (1991), "Enhancing and Measuring Consumers' Motivation, Opportunity, and Ability to Process Brand Information From Ads," Journal of Marketing, 55, 32-53.

McKinney, Vicki, Kanghyun Yoon, and Fatemeh Zahedi (2002), "The Measurement of Web-Customer Satisfaction: An Expectation and Disconfirmation Approach," Information Systems Research, 13 (3), 296-315.

McMillan, Sally J. and Jang-Sun Hwang (2002), "Measures of Perceived
Interactivity: An Exploration of the Role of Direction of Commvinication, User Control, and Time in Shaping Perceptions of Interactivity," Journal of Advertising, XXXI (3), 29-42.

Moe, Wendy W. (2003), "Buying, Searching, or Browsing: Differentiating Between Online Shoppers Using In-Store Navigational Clickstream," Journal of Consumer Psychology, 13 (1\&2), 29-39.

Nan, Xiaoli and Kwangjun Heo (2007), "Consumer Responses to Corporate Social Responsibility (CSR) Initiatives: Examining the Role of Brand-Cause Fit in Cause-Related Marketing," Journal of Advertising, 36 (63-74).

Nass, Clifford and Youngme Moon (2000), "Machines and Mindlessness: Social Responses to Computers," Journal of Social Issues, 56 (1), 81-103.

Naylor, Rebecca Walker, Rajagopal Raghunathan, and Suresh Ramanathan (2006), "Promotions Spontaneously Induce a Positive Evaluative Response," Journal of Consumer Psychology, 16 (3), 295-305.

Palazon, M. and Elena Delgado-Ballester (2009), "Effectiveness of price discounts and premium promotions," Psychology \& Marketing, 26 (12), 1108-1129.

Palla, P., R.H. Tsiotsou, and Y.T. Zotos (2013), "Is Website Interactivity Always Beneficial? An Elaboration Likelihood Model Approach," in S. Rosengren et al. (eds.), Advances in Advertising Research (Vol. IV), European Advertising Academy, pp. 131-145.

Palmer, Jonathan W. (2002), "Web Site Usability, Design, and Performance Metrics," Information Systems Research, 13 (2), 151-67.

Park, Whan, Bernard J. Jaworski, and Deborah J. Maclnnis (1986), "Strategic Brand Concept-Image Management," Journal of Marketing, 50 (4), 135-45.

Petty, R. E. and J. T. Cacioppo (1986), Communication and Persuasion: Central and Peripheral Routes to Attitude Change. New York: SpringerVerlag. 
Pieters, Rik and Michel Wedel (2004), "Attention Capture and Transfer in Advertising: Brand, Pictorial, and TextSize Effects," Journal of Marketing, 68, 36-50.

Raghunathan, Rajagopal, Michel T. Pham, and Kim P. Corfman (2006), "Informational Properties of Anxiety and Sadness, and Displaced Coping," Journal of Marketing, 32, 596-601.

Robinson, Helen, Anna Wysocka, and Chris Hand (2007), "Internet Advertising Effectiveness: The Effect of Design on Click-Through Rates for Banner Ads," International Journal of Advertising, 26 (4), 527-41.

Schindler, Robert M. (1989), "The Excitement of Getting a Bargain: Some Hypotheses Concerning the Origins and Effects of Smart-Shopper Feelings," Advances in Consumer Research, 16, 447-53.

Shi, Y.-Z., K.-M. Cheung, and G. Prendergast (2005), "Behavioral Response to Sales Promotion Tools," International Journal of Advertising, 24 (4), 467-86.

Sundar, S. Shyam and Jinhee Kim (2005), "Interactivity and Persuasion: Influencing Attitudes with Information and Involvement," Journal of Interactive Advertising, 5 (2), 5-18.

Tarafdar, Monideepa and Jie Zhang (2005), "Anallyzing the Influence of Web Site Design Parameters on Web Site Usability," Information Resources Management Journal, 18 (4), 62-80.

Teo, H.H., Lih-Bin Oha, Chunhui Liua, and Kwok-Kee Wei (2003), "An Empirical Studyof the Effects of Interactivity on Web User Attitude," International Journal of Human-Computer Studies, 58, 281-305.

Torelli, Carlos J., Ayşegül Özsomer, Sergio W. Carvalho, Hean Tat Keh, and Natalia Maehle (2014), "Brand Concepts as Representations of Human Values: Do Cultural Congruity and Compatibility Between Values Matter?," Journal of Marketing, 76 (4), 92-108.

Tsang, Melody M., Shu-Chun Ho, and TingPeng Liang (2004), "Consumer Attitudes Toward Mobile Advertising: An Empirical Study," International Journal of Electronic Commerce, 8 (3), 65-78.

Viswanathan, Siva, Jason Kuruzovich, Sanjay Gosain, and Ritu Agarwal (2007), "Online Infomediaries and Price Discrimination: Evidence from the Automotive Retailing Sector," Journal of Marketing, 71, 89-107.

Wu, G. (2005), "The Mediating Role of Perceived Interactivity in the Effect of Actual Interactivity on Attitude Toward the Website," Journal of Interactive Advertising, Volume 5, Issue 2, pp.2939.

Yang, Kenneth C. C. (2004), "Effects of Consumer Motives on Search Behavior Using Internet Advertising," CyberPsychology \& Behavior, 7 (4), 430-42.

Yi, Youjae and Jaemee Yoo (2011), "The Long-Term Effects of Sales Promotions on Brand Attitude across Monetary and Non-Monetary Promotions," Psychology \& Marketing, 28 (9), 879-96. Zettelmeyer, Florian (2000), "Expanding to the Internet: Pricing and Communications Strategies When Firms Compete on Multiple Channels," Journal of Marketing Research, 37 (3), 292-308.

Zhou, Zheng and Yeqing Bao (2002), "Users' Attitudes toward Web Advertising: Effects of Internet Motivation and Internet Ability," Advances in Consumer Research, 29, 71-78.

Zeithaml, V.A. (1988), " Consumer Perceptions of Price, Quality, and Value: A Means-End Model and Synthesis of Evidence," Journal of Marketing, 52(3), pp. 2-22. 


\section{Appendix 1: Survey Questionnaire}

\begin{tabular}{|c|c|}
\hline Constructs & Items \\
\hline \multirow[t]{5}{*}{ Symbolic } & I feel the brand shows a status. \\
\hline & I feel the user of the brand is attractive in the crowd. \\
\hline & $\begin{array}{l}\text { I feel that people using the brand as a way to express their personal } \\
\text { characteristics. }\end{array}$ \\
\hline & I feel that the brand is for people pursuing the best things in life. \\
\hline & I feel that the user of the brand is charming. \\
\hline \multirow[t]{4}{*}{ Functional } & I feel that the brand is for realistic people. \\
\hline & I feel that the brand is practical. \\
\hline & I feel the brand is for satisfying my basic needs of the product. \\
\hline & I feel the user of the brand is pragmatic \\
\hline \multicolumn{2}{|r|}{ 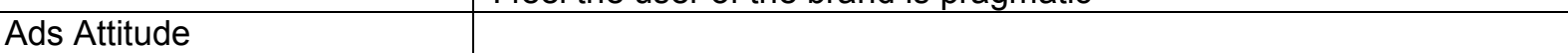 } \\
\hline \multirow[t]{3}{*}{ informativeness } & I feel that the advertisement is a good source of product information. \\
\hline & I feel that the advertisement provides timely information \\
\hline & I feel that the advertisement supplies fully relevant product information \\
\hline \multirow[t]{2}{*}{ entertainment } & I feel that the advertisement is pleasing. \\
\hline & I feel that the advertisement is enjoyable. \\
\hline \multirow[t]{2}{*}{ credibility } & I feel that the advertisement is credible. \\
\hline & I feel that the advertisement is believable. \\
\hline \multicolumn{2}{|l|}{ Product Attitude } \\
\hline \multirow[t]{2}{*}{ quality } & I feel that the product is reliable. \\
\hline & My assessment of the product is good. \\
\hline \multirow[t]{2}{*}{ value } & I feel that the product is luxury. \\
\hline & I feel that it is reasonably priced. \\
\hline
\end{tabular}

\section{Appendix 2: Data Reliability and Validity}

\section{Table A-1 - Construct reliability}

\begin{tabular}{|l|c|}
\hline \multicolumn{1}{|c|}{ Constructs } & Cronbach's alpha \\
\hline Symbolic brand & 0.93 \\
\hline Functional brand & 0.91 \\
\hline Product Attitude & 0.70 \\
\hline Ads Attitude & 0.82 \\
\hline
\end{tabular}

\section{Table A-2 - Factor analysis for brand images}

\begin{tabular}{|l|c|c|}
\hline \multicolumn{1}{|c|}{ Constructs } & Symbolism & Functionality \\
\hline Sym2 & .835 & -.277 \\
\hline Sym3 & .804 & -.326 \\
\hline Sym5 & .782 & -.380 \\
\hline Sym4 & .781 & -.447 \\
\hline Sym1 & .774 & -.441 \\
\hline Fun4 & -.349 & .847 \\
\hline Fun2 & -.284 & .844 \\
\hline Fun3 & -.429 & .793 \\
\hline Fun1 & -.473 & .710 \\
\hline
\end{tabular}




Table A-3 - Factor analysis for advertising effectiveness
\begin{tabular}{|l|c|c|}
\hline \multicolumn{1}{|c|}{ Constructs } & Ads Attitude & Product Attitude \\
\hline Ads3 & .861 & .033 \\
\hline Ads2 & .788 & .090 \\
\hline Ads1 & .662 & .040 \\
\hline Prod2 & -.150 & .878 \\
\hline Prod1 & .386 & .698 \\
\hline
\end{tabular}

\section{About the Authors}

Yuwen $\mathbf{L i}$ is a post-doctoral research fellow of the Electronic Commerce Research Center of National Sun Yat-Sen University at Kaohsiung, Taiwan. She received her doctoral degree in the same university and her primary research interests are electronic commerce and neuro information systems. Her papers have been published in International Journal of Electronic Commerce, Workshop on e-Business, and Neuroeconomics Annual Meeting, among others.

Shu-Min Yang is a tax collector of Kaohsiung Tax Collection Office in Taiwan. She graduated from the Institute of Communications Management at National Sun Yat-sen University to receive her master's degree. Prior to the current job, she had served as a merchandise project manager at the LINKYO company.
Ting-Peng Liang is a Life-time National Chair Professor at National Chengchi University in Taipei, Taiwan, on leave from National Sun Yat-Sen University. $\mathrm{He}$ received his doctoral degree from The Wharton School of the University of Pennsylvania and had taught at University of Illinois and Purdue Univeristy. His primary research interests include electronic commerce, intelligent decision support, knowledge management, strategic information systems, and neuro information systems. His papers have appeared in MIS Quarterly, Journal of MIS, Management Science, Decision Support Systems, International Journal of Electronic Commerce, and dozens of other journals. $\mathrm{He}$ is also a co-author of the recent book: Electronic Commerce: a Managerial and Social Networks Perspective (Springer). 